\title{
TECENDO VIDAS: LINHAGEM FAMILIAR E CORPOS FEMININOS: APROXIMAÇÕES ENTRE DESESTERRO, DE S. SMANIOTO, E COM ARMAS SONOLENTAS, DE C. SAAVEDRA
}

\author{
CARLOS EDUARDO BIONE (UnB) ${ }^{1}$
}

\begin{abstract}
RESUMO: Este artigo propõe-se a uma leitura comparativa dos romances Desesterro (2015) de Sheyla Smanioto e Com armas sonolentas (2018) de Carola Saavedra. A partir da matéria comum aos dois livros, a saber, a representação de uma linhagem familiar composta exclusivamente por mulheres, analisaremos a presença da violência, física e simbólica, na construção das narrativas e seus efeitos no processo de compleição das personagens. Como instrumentos teóricos teremos como ponto de partida o conceito de locus fraturado proposto por Lugones (2014), a categoria de personagem disruptiva caracterizada pela noção de trânsfuga, trabalhada por Bourdieu (1970) e Jaquet (2014) e, por fim, a proposta de Young (2003) de entender as especificidades da dinâmica entre gênero e violência a partir da noção de serialidade.
\end{abstract}

PALAVRAS-CHAVE: Sheyla Smanioto. Carola Saavedra. Narrativa de filiação. Linhagem familiar. Violência de gênero.

ABSTRACT: This article proposes a comparative reading between the novels Desesterro (2015) by Sheyla Smanioto and Com Armas Sonolentas (2018) by Carola Saavedra. From the representation of a family lineage composed exclusively of women as a common subject of these books, we will analyze the presence of physical and symbolic violence in the construction of those narratives and their effects on the process of shaping the characters. The theoretical instruments chosen are the concept of fractured locus proposed by Lugones (2014), the category of disruptive persona characterized into the notion of class-passing developed by Bourdieu (1970) and Jaquet (2014), and the Young's proposal (2003) in understanding the specificities of the dynamics between gender and violence from the notion of seriality.

KEYWORDS: Sheyla Smanioto. Carola Saavedra. Narrative of affiliation. Family lineage. Gender violence.

Para Carola, a mineira

J'écrirai pour venger ma race Annie Ernaux

\section{CORPOS SOB CONTROLE}

A família é o primeiro espaço de exercício de controle do corpo feminino.

No princípio, era o imperativo do sim. Tempos depois, houve o não como possibilidade e promessa. E foi essa a escolha circunstancial, e disruptiva, que elas fizeram, a do não.

A frase contundente, que aqui vai como epígrafe, escreverei para vingar a minha raça, escrita por uma adolescente em seu diário íntimo, soou à autora, quase três décadas mais tarde, como um tanto pretensiosa. Filha duma família pobre, que sobreviveu à ocupação nazista na França durante a II Guerra Mundial, a escritora Annie Ernaux transformou o estigma de classe e gênero, de ser filha de quitandeiros duma pequena província e com pretensões intelectuais, em pulsão para a escrita literária.

\footnotetext{
1 Doutorando vinculado ao Grupo de Estudos em Literatura Brasileira Contemporânea (GELBC/UnB), desenvolve pesquisa sobre narrativas de filiação junto ao Programa de Pós-Graduação em Literatura (PósLit) da Universidade de Brasília (UnB). E-mail: cadubione@gmail.com
} 


\section{$=$ TRAMA $=$}

Cinquenta anos depois, passados os eventos socioculturais que marcaram os anos finais da década de 1960 e as rupturas proporcionadas pelas pequenas, porém significativas, revoluções de costumes dos anos 1970, vemos surgir, numa outra ponta temporal, escritos como os da autora franco-senegalesa Fatou Diome a encenar, aproximativamente, estigmas de classe e de gênero tal qual Ernaux. Escrevivências absolutamente distintas em termos espaciais e temporais - Ernaux nascida em 1940, em Lillebonne, pequena comuna na região da Normandia; Diome, em 1968, em Niodior, vilarejo à costa atlântica do Senegal -, mas que, num horizonte de perspectiva, caminham de mãos dadas, pari passu, com as histórias de suas narrativas alinhavadas por um fio comum, o controle biopolítico exercido compulsoriamente sobre os corpos femininos que habitam o universo diegético de ambas autoras.

Se aqui fazemos referência a essas obras, num breve clin d'œil, é para apenas situarmos a nossa análise dentro de uma perspectiva, a do projeto de uma escrita de rupturas. No caso específico da autora francesa, a ruptura da reprodução de imperativos sociais e históricos que agiam silenciosamente na vida quotidiana dos habitantes, sobretudo das mulheres, das vilas interioranas da França das décadas de 1950, 1960, 1970... e, num cenário mundial de recrudescimento de conservadorismos, provavelmente, até os dias que correm. $\mathrm{Na}$ pena da autora franco-senegalesa, a ruptura de estigmas sociais e culturais legados por uma historicidade de dimensões de vultos ancestrais, fugidia a uma temporalidade perceptível.

A noção de vergonha social, categoria analítica tomada de empréstimo à sociologia bourdieusiana, verdadeiro leitmotiv para algumas obras de Ernaux, assim como para as de Diome - notadamente em La honte (A Vergonha), 1997, daquela autora, e Impossible de grandir $^{2}$ (Impossível de crescer), 2013, desta última -, parece encontrar forte eco na escrita de duas autoras brasileiras cuja produção se inscreve numa leva das mais promissoras da prosa literária contemporânea nacional. Vejamos.

\section{CORPORALIDADES FEMININAS}

Publicados com três anos de intervalo, Desesterro, de Sheyla Smanioto, em 2015, Com armas sonolentas, de Carola Saavedra, em 2018, esses dois romances exploram terrenos não tão assíduos na chamada literatura canônica nacional, a saber, a investigação palimpséstica, por assim dizer, do acúmulo de violência sofrido pelo corpo feminino, no caso de Smanioto, e, em Saavedra, a arqueologia da constituição familiar como meio de investigação das múltiplas facetas da relação parental de tipo mãe e filha - esta também conduzida pelo vasto inventário dos diferentes tipos de violência, simbólica e física, a que suas personagens estão vulneráveis pelo simples fato de serem mulheres.

Desesterro e Com armas sonolentas surgem, pois, num momento social e histórico brasileiro propício à problematização dos tipos de representação de personagens femininas no conjunto da literatura nacional. Obviamente que as motivações da escrita de cada um desses romances inscrevem-se no âmbito de um projeto autoral, das demandas específicas de produção literária de cada autora, entretanto, ambas narrativas convergem, num movimento de natural aproximação, quanto à materialidade dos enredos.

Nesse sentido, pode-se identificar, nos dois romances, independentemente das chaves de leitura adotadas pelo leitor, um espécie de núcleo-duro, com diferentes graus de similitudes, que parece impulsionar adiante ambas as narrativas. A despeito das diferenças formais evidentes de tempo e foco - no caso de Com armas sonolentas, por um lado, apesar do sequenciamento narrativo, num crescente, distribuído entre as personagens, o tempo diegético sofre, constantemente, entrecruzamentos temporais pondo personagens de épocas distintas

\footnotetext{
2 Tradução livre nossa para os títulos. Ambas narrativas ainda inéditas no Brasil.
} 


\section{$=$ TRAMA $=$}

em contato e, por outro lado, em Desesterro, temos a noção clássica de temporalidade diluída num conjunto de flashes, harmoniosos entre si, porém, distribuídos numa espécie de todo atemporal que se aproxima, em muitas passagens, ao campo do onírico, ou do trágico tal qual concebido em sua atemporalidade na antiguidade clássica, um tempo eternamente presente a engolir a todos -, tal núcleo-duro comum pode ser percebido, apesar da clara diferença de perspectiva narrativa, como a constância de um embate silencioso levado a cabo pelas personagens contra os condicionantes sociais e históricos que, em forte medida, atuam na vida dessas mulheres como verdadeiros veredictos.

Tendo-se em conta as limitações que se impõem ao escopo deste artigo, desenvolveremos uma sucinta análise das duas obras referidas abordando brevemente duas tópicas nelas problematizadas, quais sejam, (i) a questão da linhagem familiar e sua dinâmica e (ii) o imbricamento do controle em relação aos corpos femininos que a compõem.

A noção de linhagem familiar é, em certa medida, recorrente na prosa de ficção brasileira. Desde os nossos românticos, passando pelo Real-Naturalismo, pelo (Pré)Modernismo, pelo Romance de 1930, pela prosa brasileira do Pós-Guerra até os dias que correm, tal noção é trabalhada de forma produtiva, ora como símbolo de afirmação, de agregação, de pertencimento a determinado clã, a determinado grupo social, a determinada classe, ora como representação do totem familiar que precisa ser desinstitucionalizado e ressignificado.

Esse aspecto utilitário de afirmação da linhagem, de caráter reprodutivo de estruturas de poder e controle sociais, estritamente ligado à manutenção de um certo patrimonialismo caro à nossa dinâmica social, encontra, por sua vez, fortes reflexos na prosa ficcional brasileira por meio, principalmente, do seu elenco de personagens protagonistas, cuja grande maioria é composta por homens, brancos, de meia idade, profissionais liberais quase sempre ligados à intelectualidade. Tal perfil, qual paradigma reproduzido nas representações literárias dos quadros sociais brasileiros - sejam elas fruto de qualquer que seja a filiação estética ao longo do século XX -, sempre frequentou as páginas das nossas narrativas ficcionais.

Entretanto, os contornos exatos dessa representação unidimensional do corpo social brasileiro, de matriz masculina, branca e conservadora, cuja recepção junto ao público leitor médio nunca causou estranhamentos, veio à luz apenas em 2005 com a divulgação dos primeiros resultados da pesquisa As Personagens do Romance Brasileiro Contemporâneo, conduzida por Dalcastagnè (2005), na Universidade de Brasília 3 .

Mas nem tão somente a serviço da manutenção de representações estanques de classe social esteve ligado o romance brasileiro contemporâneo de abordagem familiar. Nesse sentido, Da Mata (2012) nos fornece uma alentada análise acerca dos momentos de crise da representação dessa tópica que se configura, em certa medida, como um dos núcleos duros de boa parte da prosa nacional.

Em seu estudo Como vai a família? As reconfigurações da instituição familiar no imaginário do romance brasileiro contemporâneo, o pesquisador nos chama à atenção para o papel decisivo desempenhado, no cenário literário brasileiro da década de 1950, por um romance a contrapelo, o Crônica da Casa Assassinada, de Lúcio Cardoso, exatamente como œuvre phare dessa contracorrente, de consequente tentativa de ruptura da representação monocórdica de uma linhagem familiar.

\footnotetext{
3 Os resultados preliminares da pesquisa, cujo escopo mais amplo abarca a produção narrativa nacional de 1965 a 2014, podem ser consultados no dossiê publicado no n. ${ }^{\circ} 26$, de 2005, da Revista de Estudos de Literatura Brasileira Contemporânea (PósLit/UnB).

Disponível em: https://periodicos.unb.br/index.php/estudos/issue/view/855
} 


\section{$=$ TRAMA $=$}

Enquanto um sem número de romances eram lançados reproduzindo o modelo representativo familiar clássico, legitimado socialmente, livre de turbulências mais sérias, será apenas em 1975, década e meia depois do Crônica portanto, que outra obra de fôlego, Lavoura Arcaica, de Raduan Nassar, irá agitar as calmas águas da representação romanesca da família tradicional pequeno-burguesa aclimatada ao Brasil.

A força da narrativa nassariana, nessa perspectiva, além de estabelecer um diálogo intertextual com Cardoso, atualiza o movimento proposto pela fragmentação discursiva deste e instaura a ruptura dos laços da linhagem como força centralizadora do universo diegético, negando assim o ciclo de expurgo e purificação pelo qual o filho, subversivo da ordem familiar - em larga medida representando um tipo de símile do bouc émissaire ${ }^{4}$, do qual nos fala Girard (1982) -, deveria obrigatoriamente passar para, uma vez purificado, ser reinserido ao núcleo familiar, configurando, por fim, uma trajetória de queda e redenção, verdadeira ascese purgatória em prol dos valores familiares vigentes.

Num contexto diverso àquele, observamos, tanto em Desesterro quanto em Com armas sonolentas, uma noção de linhagem familiar atualizada e representada como parte substancial da matéria romanesca a ser problematizada. Vejamos.

Em Desesterro, ela apresenta-se na encarnação de quatro gerações de mulheres que vivem sob o mesmo teto, a matriarca e suas descendentes, uma delas morta quando dum parto, mas presentificada pelo discurso da mãe exatamente por reclamar sua ausência a todo o momento. Todas elas, vivas ou mortas, estão submetidas à mesma figura masculina, violenta, abusiva e opressora.

Segundo Smanioto, o mote inicial do romance teria sido trabalhar os temas da fome e da migração, e as metáforas que esses temas poderiam sugerir para a construção do universo de suas personagens. Descendente de uma família com origens no Nordeste do país, a autora decide enfrentar esses temas, frequentes no romance brasileiro, a partir de uma perspectiva diferente. Assim, tem-se como resultado, além do inovador e denso trabalho estilístico empreendido pela autora estreante, o estabelecimento de dois paradigmas para o desenrolar da trama, a saber:

(i) por um lado, o tema da fome que, costumeiramente trabalhado em termos de estigma social a assombrar exclusivamente habitantes daquela parte do país, o Nordeste, na escrita de Smanioto, entretanto, o tema é deslocado dessa perspectiva única e disseminado em múltiplos sentidos, como uma força motriz das personagens que povoam o tempo e o espaço do seu romance. Em Vilaboinha, cenário de onde parte a narrativa, todas as personagens sentem fome, porém, cada qual à sua maneira. No caso específico da figura masculina, parte integrante e, ao mesmo tempo, antagonista da linhagem feminina, sua fome, ou melhor, suas fomes, no plural, configuram-se como a essência constituinte daquela masculinidade em todos os seus avatares: o marido, o companheiro, o agregado, o padrasto, todos eles abusivos e opressores.

Dessa forma, o leitmotiv inicial da fome, da fome fisiológica propriamente dita, passa, posteriormente, a desdobrar-se em outras formas simbólicas de fome: fome de autoridade, fome de poder, fome de abuso, fome de corpos, chegando, por meio duma escrita em convulsão, ao paroxismo desse estado constante de insaciedade com a metáfora totalizadora da terra, que come e descome os corpos indigentes dessas mulheres periféricas num mundo

\footnotetext{
${ }^{4}$ Em sua obra Le bouc émissaire [O bode expiatório], o antropólogo René Girard propõe, por meio da análise dos mitos presentes em diferentes civilizações, uma genealogia da violência primitiva coletiva. Apesar de criticado por desenvolver suas análises sob forte presença do cristianismo - em rota de colisão com a antropologia estruturalista francesa -, acreditamos que seus estudos, ainda assim, nos fornecem produtivas chaves interpretativas para o fenômeno, atávico às sociedades humanas, da violência.
} 


\section{$=$ TRAMA $=$}

duplo de desterro, inicialmente circunscrito à Vilaboinha, depois, na segunda parte do romance, estendido à Vila Marta - sempre à margem 5 .

Em meio ao vórtice da narração, o leitor não consegue, a priori, definir muito bem, de forma fixa, a que papel familiar a figura masculina corresponde em relação a essa linhagem de mulheres. Com o avançar da narrativa, no entanto, os traços abusivos dessa figura masculina ganham contornos mais claros. A única coisa certa e constante é o poder opressor de sua presença a assombrar/devorar todas as mulheres da família.

Uma das passagens mais fortes do romance, da qual extraímos o fragmento a seguir, é construída a partir de uma quebra narrativa em que aparece, num monólogo que se estende ao longo de quatro páginas, a voz da figura masculina, em discurso direto e cru, tentando balbuciar a narração, a partir da sua perspectiva, de um episódio de violência sexual que cometera contra uma criança da família, sua enteada:

um homem tem que fazer suas coisas, nem toda mulher é boa mulher, diacho [...] Ela [a menina, sua enteada] ficava na terra com as pernas arreganhadas, ela pequena e me fazendo querer arreganhar de vez aquelas pernas. Eu falei pra ela, conheço esse jogo de rapariga, esse jogo de quer não quer, eu sei bem o que você quer. Eu falei pra ela, eu sou boa pessoa, diacho, você sabe que já tinha era morrido de fome se eu não tomo conta de você, de sua mãe Aparecida [...] Desde pequena sentada na terra com aquelas pernas, e agora que eu ia ter o que é meu isso é jeito? Eu fui um pai pra ela, minha tia, não quero que ela ache que sou má pessoa, então expliquei volte aqui eu gritei, mesmo na escuridão eu expliquei, ela é minha por direito [...] Eu entendo esses jeitos de mulher dizer quer não quer, minha tia, mas a vida não é só o que você quer, eu falei pra ela, eu falei quando ela começou a se debater, a cadelinha pregada na minha canela. A vida é dura, Maria de Fátima, você está achando o quê? Eu sei que isso é jogo de mulher quer não quer, eu sei que você quer ou não tinha as pernas assim meio abertas, diacho, os peitos desse jeito embaixo dos panos, anda, aproveita que sua mãe não está olhando, eu sei bem o que você quer. É normal ter medo, eu falei pra ela enquanto ela se debatia, a cadela na minha canela, é normal sentir dor, eu falei enquanto ela se debatia comigo nela, diacho, gostoso demais. No começo eu achei ela tinha entendido, mas a rapariga falou pra eu parar [...] Diacho, você não pode mudar de ideia no meio em caminho, eu bem que falei sem nem parar claro que não, você foi deixando as pernas soltas esse peito perto de fora da roupa diacho esses peitinhos perto de mim que sou louco em mulher, queria o quê? (SMANIOTO, 2015, 110-111).

É nessa súbita troca de foco narrativo que a autora põe a nu a armadilha discursiva do agressor ao tentar, a todo instante, transferir para a vítima da violência, sua enteada, a então menina Maria de Fátima, a responsabilidade pelo estupro que sofrera. Tem-se, na referida passagem, e ao longo de todo o monólogo, a arquitetura de um discurso sexista e denegatório, que imputa à vítima da violência a marca original da culpa.

Antes, porém, de caminhar por atalhos fáceis e traçar uma caricatura do provedor abusivo que tudo faz e tudo pode, a autora delineia finamente, com pleno domínio da sua escrita, as contradições estruturantes que conformam essa figura arquetípica do pater familias dentro da tradição socio-histórica brasileira ${ }^{6}$. Assim, a ação prosaica de comer, de saciar a fome

\footnotetext{
${ }^{5}$ Nesse aspecto, há que se desenvolver ainda uma análise sobre o imbricamento dos aspectos sociais e topográficos com as formas de violência exercidas/sofridas por essas personagens periféricas na luta pela sobrevivência. Smanioto desenvolve, dentro do espaço diegético de Desesterro, uma fina crítica às condições de "vulnerabilidade total" e negligência institucional a que estão expostas as mulheres de seu romance. Para uma abordagem sobre essa perversa dinâmia social, remeto o leitor ao artigo de BURLANDY e MAGALHÃES. A dura realidade brasileira: famílias vulneráveis a tudo. Democracia Viva, Ibase, n. 38, jun. 2008.

${ }^{6}$ Remetemos o leitor interessado nessa tópica a um estudo de referência sobre o tema realizado pelo historiador Ronaldo Vainfas (UFF), notadamente ao capítulo IV, Patriarcalismo e misoginia, do seu livro seminal para os estudos brasileiros, Trópico dos Pecados, de 1989, para uma visada panorâmica, por meio do enfoque da
} 


\section{$=$ TRAMA $=$}

fisiológica, assume, dentro do espaço de sentido do masculino, uma dimensão metafórica - e empírica - do exercício de controle e de poder sobre o corpo das mulheres da família. Oprimese e abusa-se um corpo feminino na mesma dinâmica simbólica da tomada de um dado alimento para saciar a(s) fome(s) do corpo/locus masculino;

(ii) por outro lado, temos o segundo paradigma, o da migração que, deslocado geograficamente, adquire novo marco espacial. Aquele que, na tradição histórica e literária brasileira do século XX, movia-se no sentido Nordeste-Sudeste, em Desesterro, passa a ser trabalhado no eixo periferia-centro, este centro delimitado sempre como o horizonte inalcançável - acredito que não seja equivocado pensarmos aqui nessa dinâmica como um tipo de alegoria da própria configuração excludente e problemática dos grandes centros urbanos brasileiros e como essa política da exclusão torna ainda mais vulnerável e precária a existência de mulheres periféricas.

De Vilaboinha à Vila Marta, duas faces dum mesmo desesterro, dá-se a trajetória, de vida e de fuga, dessa linhagem de mulheres, especificamente com as duas últimas, Maria de Fátima e sua filha Scarlett Maria, numa espécie de eterno estamos quase chegando lá, em que este lá é percebido como o centro desenvolvido, um espaço de promessa de uma vida melhor, logo, lugar instituído como meta, mas que, uma vez alcançado, materializa-se como duplo do espaço anterior. Vilaboinha e Vila Marta, do mesmo ao mesmo, duas periferias que, num jogo de imagem, refletem-se parcialmente uma na outra replicando o mesmo cenário de violência, vulnerabilidade e negligência a que esses corpos femininos periféricos estão expostos.

Esse deslocamento fugitivo como promessa de devir, de uma vida melhor, para essas Marias, porém, não se realiza exatamente como esperado. Nessa perspectiva, acreditamos que a narrativa alcança um dos seus pontos mais importantes ao mostrar para o leitor que, não importa por onde essas personagens se movam, a ameaça de uma estrutura social opressora e violenta estará sempre à espreita.

A superestrutura, nesse sentido, seria apenas a parte visível e atualizadora da manutenção de mecanismos subterrâneos de controle, físico e simbólico, a agir sobre a vida e a morte dessas personagens. A mudança de cenário, de uma periferia à outra, em nada modifica a sorte dessas mulheres, condenadas que estão a migrar em círculos - essa ideia de mulheres movendo-se dentro dum circuito fechado, não por acaso, também é trabalhada por Saavedra, em seu Com armas sonolentas, como veremos mais adiante.

Nesse ponto, a crítica da escrita smanioteana aprofunda-se numa análise sobre os destinos possíveis dessas mulheres submetidas à violência e à opressão, não de uma figura masculina isolada, mas de um conjunto de relações, de um modelo de estrutura social que parece, ela própria, retroalimentar-se por meio de dispositivos de afirmação, reprodução e demandas renovadas de uma masculinidade agressiva, abusiva, opressora, tóxica enfim.

A trajetória das Marias de Desesterro, partindo duma completa anomia social ${ }^{7}$ para uma precariedade periférica às bordas do centro, será abruptamente interrompida no anonimato (cúmplice?) de mais um feminicídio. Esse lugar fraturado da ausência/presença e do silenciamento do corpo feminino é insinuado, a todo instante, pela narrativa e atinge a sua forma mais contundente na assertiva da narradora ao afirmar, em tom de conversa falsamente

história social, de como esse lugar de sentido colado ao masculino, sobretudo quando se trata do locus do pater familias, foi forjado ao longo da história da sociedade brasileira.

${ }_{7}$ Ampliamos aqui a noção de anomia social (desajustamento estrutural, social e psíquico) estabelecida pelo Professor e Sociólogo Florestan Fernandes ao analisar a dinâmica de exclusão social, posterior à impossibilidade de inserção, da população negra no Brasil do período após abolição do regime escravocrata (1888), especificamente na virada do século XIX para o XX com o estabelecimento do modelo social de produção capitalista nos grandes centros urbanos do sudeste do país. Cf. FERNANDES, F. A integração do negro na sociedade de classes: no limiar de uma nova era. SP, 1965. 


\section{$=$ TRAMA $=$}

prosaica, "Tonho tantas vezes batendo em Fátima ela nem se importa, mulher nenhuma morreu de apanhar do marido, exceto as que estão mortas. Olha, quase não tem marca" (SMANIOTO, $2015,106)$ [grifos nosso].

Desesterro desenvolve-se num complexo trabalho de enredamento narrativo com diferentes temporalidades e perspectivas sobrepondo-se umas às outras. Sua forma mimetiza, em certa medida, o intencional embaralhamento discursivo típico de agressores e põe a nu a contaminação sofrida pelas falas e percepções das vítimas, aprisionadas que estão dentro desse universo regido pela palavra de lei masculina, dinâmica típica do exercício de poder do patriarcado, do pater dixit.

Fragmentos de frases tais como "mas ele cuida de mim", "ele só quer o meu bem", "ele vai-se explicar", "ele vai-se desculpar" evoluem, a pouco e pouco, para um "mas ele disse que foi minha culpa", "que eu provoquei", "que eu mereci", denunciando assim os mecanismos de persuasão de culpa do agressor e a manutenção do ciclo de violência a que estão presas essas personagens.

Ao refletir, especificamente, sobre os sentidos do movimento migratório no seu Desesterro, Smanioto refere-se à sua própria trajetória como filha duma família cuja origem ancestral remonta ao Nordeste do Brasil e que migraram para São Paulo. A autora menciona igualmente em suas intervenções públicas, em falas que remetem a um contínuo exercício de autoanálise sociológica, ter alinhado o seu passo à trajetória familiar uma vez que sua vida também é marcada pela migração urbana e social, da periferia para o centro de São Paulo ${ }^{8}$. Exatamente esse pensar a própria trajetória opera uma mudança significativa da abordagem dada ao tema, pois não se trata mais da observação de um outro distanciado - perspectiva, via de regra, assumida pelo romanceiro nacional ao abordar o tema da migração.

Nos termos do sociólogo Didier Eribon, esse pensamento crítico acerca da própria trajetória ${ }^{9}$, trabalhado em seu livro Retour à Reims, teria o poder de deslocar a visada analítica quase sempre direcionada exclusivamente para o outro, sobretudo numa terceira pessoa (singular e/ou plural), para uma abordagem de dinâmica relacional do eu consigo mesmo, com os outros - incluindo-se sobretudo o tu leitor - e com o mundo que o cerca. Longe de ser uma empresa egóica, tal abordagem retira esse eu ensimesmado da "nuvem imaginária" da neutralidade analítica e, mais sinceramente, aproxima-o de sua real condição, de sua realidade material, do seu sentido de valores, pois, uma vez participante, também ele é produto e produtor de sentidos uma vez que inserido na/atravessado por essas dinâmicas ${ }^{10}$.

Partindo dessa visada, da díade fome/migração, Smanioto desenvolve o quadro familiar que habita o seu Desesterro. A indiferenciação que caracteriza o percurso de vida dessa linhagem de Marias, constituídas pela fome e pelo migrar, de uma geração a outra, submetidas

\footnotetext{
${ }^{8}$ São vários os depoimentos da autora sobre a feitura do romance e a sua trajetória de "jovem branca periférica e de cultura essencialmente negra" que rompeu o veredicto social a que estava "destinada" ao transpor os limites impostos ao corpo feminino periférico e conseguir formar-se Mestra em Estudos Literários pela Universidade Estadual de Campinas. Cf. Sheyla Smanioto e Desesterro. São Paulo Review. Vídeo divulgação disponível em: bit.ly/309KhBX ; Casa Bondelê FLIP 2018: Bate-papo com Sheyla Smanioto, autora de Desesterro, bit.ly/2DyM4al ; Avesso do Avesso II - Segunda jornada organizada pelo coletivo A Entidade, do curso de Estudos Literários do Instituto de Estudos da Linguagem (IEL-UNICAMP), bit.ly/2qRcKRc.

${ }^{9}$ «Un retour à son lieu d'origine mais, surtout, un retour vers la construction possible d'une compréhension de sa propre trajectoire » [Um retorno ao seu lugar de origem, mas, sobretudo, um retorno no sentido da construção possível de uma compreensão da própria trajetória], em ERIBON, D. Retour à Reims, 2009. (trad. livre nossa).

10 Remetemos o leitor à concepção adorniana de sujeito da análise cultural feita a partir de um local situado/ocupado pelo observador no interior mesmo da dinâmica da produção cultural e, desta forma, um discurso, em si, atravessado pelos conflitos próprios que dão forma a tais produções, questão desenvolvida, entre outras, em sua obra, a quatro mãos, Dialética do Esclarecimento (ADORNO, T. e HORKHEIMER, M., 1944).
} 


\section{$=$ TRAMA $=$}

à violência física e simbólica, assume contornos de uma temporalidade fugidia na qual passado e futuro confundem-se dentro da atmosfera de opressão do presente.

A nomeação repetitiva, trabalhada mais detidamente na segunda parte do segundo capítulo, intitulado Duas vezes nascida, demonstra bem a circularidade a que as descendentes daquela linhagem estão condenadas. A personagem mais velha da narrativa, a avó Maria da Penha, é apresentada como uma retomada da sua própria avó, nomeada igualmente Maria da Penha. Essa repetição é justificada, na voz narrativa, por dois motivos: ou por admiração a um nome santo ou por caracterizar a personagem como ex-voto de uma promessa feita pela sua progenitora. Nesse aspecto, a partir dessas duas possibilidades complementares de conformação das personagens descendentes, observamos claramente os dispositivos que acionam os mecanismos de transmissão dentro daquela linhagem: a fé religiosa, por uma lado, e a noção de dívida por graça alcançada, por outro.

Maria da Penha, Maria Aparecida, Maria de Fátima e Scarlett Maria. São todas elas Maria. A repetição de nome, trabalhada também no capítulo Maria, Maria..., de imediato, remete-nos à cena de apresentação do eu narrativo do auto de natal cabralino Morte e Vida Severina: somos todas Marias/iguais em tudo na vida é o eco presente ao longo de toda a narrativa. Esta possível paráfrase do arquétipo da linhagem negativizada a que todas as descendentes estão condenadas, numa espécie de maldição a se repetir, assume contornos mais atuais de tragicidade em Smanioto na medida em que a violência nela encenada não é fruto apenas de uma estrutura social economicamente desigual e perversa, mas é, também e principalmente, o produto de um tipo específico de violência, a de gênero.

A apresentação da genealogia familiar, feita naquele capítulo, ao mesmo tempo em que parece condenar as descendentes dessa linhagem à maldição de uma circularidade sem fim, também esboça pequenas fraturas nesse todo monolítico opressor dentro do qual as personagens se movem. Pequenos movimentos de resistência que se vão acumulando rumo a uma ruptura futura maior, qual o modus operandi das pequenas armas dos fracos ${ }^{11}$.

\section{INSTAURAÇÃO DO LOCUS FRATURADO}

Em seu ensaio, Rumo a um feminismo descolonial, Lugones (2014) nos fala de um entre-lugar, um lócus fraturado, de "colaboração e conflito intersubjetivos", espécie de habitat "construído duplamente, que percebe duplamente [e que] relaciona-se duplamente", onde os seus múltiplos lados estão em constante tensão, em constante atrito, e onde esse "próprio conflito informa ativamente a subjetividade do ente" como um lugar de encenação de ambiguidades por excelência. Ainda com a autora, a refletir sobre a conformação desse espaço dual, conflitivo, de resistência possível, podemos pensar a trajetória de Maria de Fátima, cedendo/transgredindo mesmo que minimamente, aceitando/negando, em permanente negociação (i) com o seu algoz, invasor do seu corpo, e (ii) consigo mesma pelo direito de habitar-se a si.

Após atravessar uma jornada marcada por violências, Maria de Fátima decide traçar uma linha de fuga possível. A protagonista, até então submetida ao arbítrio, muda seu percurso

\footnotetext{
${ }^{11}$ Fazemos referência à expressão cunhada por James C. Scott, em seu Exploração normal, resistência normal, de 2011, obra essencial para pensarmos nas diferentes formas possíveis de resistência em contextos opressores e de exploração física e moral. Apesar de o autor desenvolver seu estudo numa chave de análise, majoritariamente, de crítica marxista, a partir da noção clássica de luta entre classes, operários versus proprietários dos meios de produção, desenvolvemos nossa reflexão aqui, a partir dos pequenos mecanismos de resistência apontados no ensaio, deslocando a chave de análise pura e simplesmente do âmbito da luta de classes para o terreno do gênero, pois acreditamos que, antes de serem entendidas como arenas específicas de disputas sociais, classe e gênero estão intrinsecamente unidas a condicionar as trajetórias dos atores sociais.
} 


\section{$=$ TRAMA $=$}

e o faz, não como uma heroína romantizada, a partir duma tomada de consciência solitária e radical, mas como um elemento dotado de agência e resultante da rede de movimentos ${ }^{12}$ que se foram acumulando ao longo do seu tempo até a criação de uma frágil, porém existente, comunidade de afinidades, mesmo que silenciadas, escondidas, secretas, mas que terminaram por impulsionar a personagem em direção à fuga - ergue-se e rompe, por fim, a circularidade do seu pertencimento compulsório, do seu veredicto social.

A ruptura na sequencialidade circular dos destinos da família, instaurada pela fuga de Maria de Fátima, abre uma fresta para pensarmos a trajetória dessa que ousou romper a lei da ordem familiar. A categoria de trânsfuga, trabalhada por Bourdieu paralelamente ao seu estudo sobre os mecanismos da reprodução social ${ }^{13}$, pode nos ser produtiva para pensarmos o percurso dessa mesma Maria que, por um lance do acaso, torna-se outra Maria. Nesse sentido, os contornos da agora trânsfuga Maria de Fátima passam a ser redelineados na narrativa como aquela que instaura e encarna a própria desordem da sua linhagem. E por isso será sacrificada.

Curiosamente, esse lugar de fratura (LUGONES, 2014) que passa a ser ocupado por Maria de Fátima, de tomada de uma outra perspectiva, de projetos para essa outra mulher, de devires possíveis, é, no entanto, em Desesterro, um lugar impossível, pois, ao correr da leitura, o leitor dá-se conta de que a personagem já não possui corporeidade. A promessa daquela outra vida, em Vila Marta, nos é narrada pela voz fantasmagórica da filha trânsfuga. Maria de Fátima é sacrificada e o projeto de uma vida longe de Vilaboinha só é levado adiante pela sua filha Scarlett Maria, esta encarnando e performando as rupturas provocadas pela mãe, a começar pelo próprio nome que, para além de fazer referência "a uma artista de cinema", rompe o sequenciamento "natural" da linhagem de nomear suas descendentes como se ex-voto fossem.

Nesse sentido, Scarlett Maria não seria, como todas da linhagem que lhe antecederam, resultado de uma graça alcançada antes ou quando do seu nascimento. Nascer, nasce-se sempre. Scarlett é, assim, ela própria, a sua promessa de devir afortunado - mesmo que precário, qual o folhetim romântico em tecnicolor fonte de inspiração para a escolha de seu nome de batismo.

\footnotetext{
${ }^{12}$ Cf. as categorias ingenium e compleição trabalhadas pela filósofa Chantal Jaquet na obra Les transclasses ou la non-reproduction, de 2014, ao refletir, em diálogo com o estudo sobre a "reprodutibilidade social" desenvolvido por Bourdieu e Passeron (1970), sobre a construção de combinações de regras geradas e entrelaçadas dentro do próprio tecido social no qual o sujeito está imediatamente inserido em detrimento do diagnóstico fácil de um desregramento instaurado exclusivamente por um agente. Nessa chave de abordagem, a autora desenvolve um debate sobre a nomenclatura atribuída à categoria do trânsfuga, chamando atenção ao peso negativo que o termo trouxe para a percepção do fenômeno, pois, etimologicamente, o termo faz referência à figura do desertor, do traidor. Resta analisar, nos casos específicos de cada personagem, até que ponto esse campo semântico de deserção/traição pode ser aplicado no sentido de uma transgressão da deontologia familiar. Para Jaquet, entretanto, esse caminho analítico quase inquisitorial pode/deve receber novo fôlego, menos acusatório, se as noções de ingenium e compleição forem consideradas no estudo da trajetória dessas personagens disruptivas.

13 Tal noção, trabalhada por Bourdieu e Passeron em La Reproduction. Éléments pour une théorie du système d'enseignement, de 1970, apesar de circunscrita ao âmbito da educação nacional francesa, instituição estudada em sua estrutura reprodutora pelos sociólogos, num momento posterior, será retomada em outros escritos de Bourdieu no sentido de perceber, na vida social após a educação formal nos bancos escolares, a permanência e manutenção dos mesmos mecanismos de reprodução social a serem replicados, na dupla chave da integração e da exclusão, não só nas estruturas integrantes do aparato Estatal, mas, também, e sobretudo, na vida citadina dos diferentes atores sociais, mesmo aqueles os mais distantes e aparentemente despossuídos de capital social decisório. Nesse sentido, articulamos aqui à noção de reprodução social a categoria de trânsfuga trabalhada mais detidamente por Bourdieu em seu escrito Les contradictions de l'héritage que integra a obra La misère du monde, cuja primeira aparição data de 1993.
} 


\section{$=$ TRAMA $=$}

\section{CORPOS SONOLENTOS}

A trajetória das personagens saavedreanas, em Com armas sonolentas, em parte, assemelha-se à trajetória das Marias de Smanioto. Talvez duas principais diferenças distingamnas, a primeira, a presença permanente, ao longo de toda a narrativa, de uma ambiência fantástica, insólita, limítrofe sempre prestes a irromper no mundo das personagens e a misturarse ao discurso narrativo, criando assim uma atmosfera permanente de expectativa para uma possível reviravolta da matéria narrada, de armas prestes a despertar. A segunda diferença diz respeito ao foco assumido pela narradora e a consequente visão desenvolvida quanto ao conjunto de violências sofridas pelas cinco gerações de mulheres que habitam o seu romance.

Se em Desesterro o tema da violência, em certas passagens, coloca o leitor diante da acusação das agressões, da potência de uma fala que enfrenta, de maneira simultânea, essas agressões e o agressor, em Com armas sonolentas, por outras vias, a narrativa nos põe diante da crua naturalização, social e histórica, da violência de gênero, diante da instrumentalização premeditada dum discurso de nuances altruístas com vistas à manutenção do controle de corpos, diante da vulgar e cotidiana renovação do exercício de uma biopolítica típica por essas latitudes.

Partindo, numa ponta, de uma matriarca de origens indígenas e chegando, noutra ponta, às buscas existenciais de uma intelectual, a narrativa de Saavedra constrói a saga de uma linhagem de mulheres: trisavó, bisavó, avó, mãe, filha. Nesse painel familiar que mimetiza e remonta, sob um foco específico, às próprias origens da formação do povo sul-americano, percebe-se a permanência da violência em suas diferentes formas como elemento constituinte comum a ligar a trajetória de vida dessas mulheres, aparentemente, diferentes em tudo.

Em Smanioto, a crítica à opressão e à violência de gênero é trabalhada a partir de uma visão de semelhança repetitiva de nome, de corpo e de sina das suas Marias, já em Saavedra, por outro lado, o processo de diferenciação social por que passa o seu elenco será o caminho para construir cada uma de suas personagens. Mas atenção, não se perceba essa nãosimilaridade entre as personagens de Saavedra, em oposição às Marias em série de Smanioto, como um dado de distinção individual. Percebemos, antes, essas diferenças conjunturais na composição das personagens de Com armas sonolentas como um duplo artifício narrativo: por uma via, ele contribui para reforçar a percepção da evolução temporal da narrativa, por outra, ele aprofunda a denúncia de que a violência de gênero independe da estratificação de classe.

Se, no romance de Smanioto, a cena-motriz da violação do corpo feminino infantil se passa sob a luz do sol, em Com armas sonolentas, ela acontece longe do olhar dos outros, protegida por detrás de grossas e firmes paredes, nos fundos da área de serviço de um amplo apartamento em Copacabana. Em tudo, a forma como é apresentado o futuro cenário de trabalho - leia-se explorações - da personagem nos conduz à construção de uma percepção de "naturalidade":

Dois dias depois, dona Neusa foi pessoalmente buscá-la na casa da mãe, dona Neusa era muito boa e prestativa e iria com ela até o Rio de Janeiro, até a casa dos seus patrões, foi o que disse a mãe, e lhe pareceu muito estranha aquela palavra, patrões, puxando-a para uma realidade inconcebível, a casa da minha prima, explicou dona Neusa, fica em Copacabana, é um apartamento enorme, com muitos quartos e banheiros, móveis de jacarandá e uma vista linda, você vai adorar, eles moram perto da praia, já imaginou, pertinho do mar, já imaginou, você anda uns minutinhos e pronto, está na praia de Copacabana (SAAVEDRA, 2018, cap. Avó, sem paginação) [grifos nossos].

Dentro desse conhecido universo de "luta", de "trabalho", de "batalha cotidiana por uma vida melhor", alguém poderia pensar: "mas, afinal, ela [a personagem da avó] teve a 


\section{$=$ TRAMA $=$}

oportunidade de deixar para trás uma realidade miserável e, por meio do seu trabalho semiescravo, há que se registrar -, conseguiu ter uma vida menos precária"... e assim se vão acumulando as camadas de percepção tortuosa da realidade que constituem nosso corpo histórico e social - e a narradora saavedreana, a todo instante, parece nos chamar atenção exatamente para essa percepção naturalizada de um conjunto de violências "invisíveis".

Talvez, a face mais perversa dessa representação social construída pela escritora sejam os efeitos da recepção do romance junto aos leitores no que diz respeito a possíveis dúvidas sobre a materialidade da violação sofrida pela personagem da avó, então adolescente quando do fato. Nessa linha de leitura, parece-nos bastante sintomática a contiguidade que se pode estabelecer entre o monólogo denegatório do estuprador de Desesterro e a dúvida do leitor diante da materialidade ou não da violência sofrida pela jovem, trabalhadora doméstica, em Com armas sonolentas.

É exatamente dessa aparente impossibilidade factual de percepção do grau de violência a que se está submetida - e de sua naturalização - que trata o romance. A violação envolta em frases e gestos bem intencionados é apenas a face menos dissimulada de um complexo emaranhado de relações historicamente baseadas em múltiplas práticas exploratórias - e o corpo feminino, parece-nos, aqui, ser alçado à categoria de "insumo fundacional" dentro dessa dinâmica de violências.

Assim, numa visada mais ampla, o romance nos apresenta, uma linhagem familiar esboçada num variado arco de tipos sociais que recobre, de forma alegórica, o espaço/tempo da conformação socio-histórica sul-americana dos últimos quinhentos anos: numa ponta, uma matriarca ameríndia, noutra, em circunstâncias que só as sinuosidades da escrita saavedreana conseguem explicar, uma jovem acadêmica de Estudos Brasileiros numa universidade alemã.

Paralelamente, ao observarmos mais detidamente sua estrutura, vemos que o romance desenvolve, como num estudo de casos, noutro nível de leitura, a análise dos diferentes tipos de maternidade presentes nessas cinco gerações e, consequentemente, a dinâmica intergeracional estabelecida nos pares mãe-filha e avó-neta.

Saavedra desenvolve, nesse aspecto, um interessante quadro em que as relações familiares parecem obedecer a dispositivos geracionais, num sentido que chega a se aproximar dos imperativos de uma antropologia biológica praticada na segunda metade do século XIX. É certo que tal perspectiva estruturante da narrativa coaduna-se com a crítica subjacente - forte marca do romance - aos discursos desenvolvidos ao longo do processo colonizador dos povos nativos americanos.

Observemos, então, o quadro:

1. Trisavó: de origem indígena, vive com a filha e netos, num contexto de grande pobreza, no interior do Rio de Janeiro. Esse cenário inicial, pelas características e funções que assume assemelha-se aos aldeamentos indígenas instituídos no período colonial;

2. Bisavó: tem-se poucas informações sobre ela, apenas que trabalha duramente para sustentar sozinha sua prole. Recebe proposta de entregar (vender?) uma de suas filhas, ainda criança, para ir trabalhar na casa duma família abastada em Copacabana. "Eu já fiz o meu papel, já te criei, te alimentei, sacrifiquei minha vida por sua causa, agora suma daqui que eu já tenho peso suficiente para carregar" (SAAVEDRA, 2018), é o argumento dessa mãe ao entregar a filha;

3. Avó: a filha entregue, aos quatorze anos, para ser doméstica a vida inteira num apartamento em Copacabana. Passa a ser molestada pelo filho mais velho dos patrões, engravida, tem uma filha, Anna, depois do parto, sob efeito de mais uma violência, a higienista, disfarçada em discurso filantrópico, é histerectomizada compulsoriamente pelo médico dos patrões; 


\section{$=$ TRAMA $=$}

4. Mãe: Anna, criada ocupando um duplo lugar, ora como filha da doméstica, ora como neta da patroa. Anna representa o lugar fraturado inicial onde se dará a ruptura do acúmulo sucessivo dos veredictos impostos à linhagem familiar presa num círculo de violências. Anna conhece um alemão, muda-se com ele para a Alemanha, engravida e, tomada por forte depressão pós-parto, rejeita a maternidade;

5. Filha: Maike, o elo perdido da linhagem, é abandonada num bosque na Alemanha. Chama atenção como essa personagem nos é apresentada: "Tudo começou no dia em que eu decidi estudar português. Ou talvez tudo tenha começado bem antes, quando Max enfiou uma faca nas minhas costas" (SAAVEDRA, 2018). Com Maike, filha adotiva de uma rica família alemã, a priori completamente afastada daquele cenário inicial do romance, de reprodução de violência estrutural, o topos da violência, das marcas físicas da colonização do corpo, entretanto, é recuperado como uma marca constitutiva da linhagem, em Maike, na forma duma cicatriz de facada nas costas de que foi vítima ainda na infância.

Podemos observar, nesse quadro sucinto das personagens do romance, uma característica curiosa sobre a maternidade. Como a referência feita anteriormente sobre uma provável "antropologia biológica" a estruturar a narrativa - tendo no horizonte interpretativo que o romance surge da necessidade da autora de desenvolver uma escrita sobre as nuances das relações entre mãe e filha -, Saavedra constrói um topos da maternidade à semelhança das características hereditárias usadas naquele contexto de determinismo positivista para traçar permanências fisiológicas atávicas em indivíduos de determinada linhagem.

A maternidade, nesse sentido, entendida como conjunto de atributos maternos em relação à prole, é trabalhada na narrativa como um traço(/mal?) hereditário a manifestar-se, de maneira alternada, ao longo das cinco gerações.

Mudando, porém, essa chave interpretativa, numa leitura menos crua e mais atenta aos condicionantes sociais das circunstâncias em que se encontram essas personagens, podemos entender a relação entre as gerações como um inverso a equilibrar e complementar a dinâmica familiar: a figura duma trisavó/matriarca pegada às suas tradições místicas, com suas ervas e rezas a benzer e purificar os familiares $\Theta$ relação esta que é equilibrada pelo senso pragmático de sobrevivência da bisavó/filha abandonada pelo companheiro/pai dos seus filhos e preocupada em prover alimento para a família $\rightarrow$ avó/neta, empregada doméstica, a sonhar com as histórias de amor das sessões de cinema a que assiste no seu único dia de folga, sem se dar conta da violência contínua a que está submetida $\Theta$ relação esta pretensamente equilibrada pelo senso prático, de instrução pequeno-burguesa da filha Anna, mãe/bisneta $\rightarrow$ Maike, filha/trineta, núcleo insular da linhagem que, no recorte temporal do romance, acaba por não dar continuidade à descendência familiar.

Um aspecto importante da narrativa de Com armas sonolentas, quanto ao trabalho empreendido à noção de linhagem, é o percurso disruptivo da última integrante da família. A um só tempo, Maike abandona a sua zona de conforto de intelectual no contexto europeu, se investe numa aventura tropical, como um expedicionário alemão do século XVIII, a desbravar os mistérios de um Novo Mundo que Ihe é estranho e, ao mesmo tempo, inexplicavelmente familiar, reencontra, numa experiência mística, os passos de sua ancestralidade, mas, também, acaba por saltar para fora dessa fita de Möbius a que as gerações precedentes estiveram presas.

Nesse aspecto, podemos interpretar a saída à francesa da personagem Maike do círculo narrativo do romance como mais uma etapa alcançada do processo iniciado por Anna a partir da sua condição de ente familiar presa a um locus fraturado, a ocupar um espaço filial atravessado, por um lado, pelos laços maternos, pelo sentimento de pertencimento àquela linhagem de mulheres exploradas em todos os aspectos, e, por outro lado, pela sedução de ser 


\title{
$=$ TRAMA $=$
}

a neta mimada - ilegítima - de uma família que, ao mesmo tempo, lhe acolhe, instrui, coopta e continua a explorar a miséria de sua mãe. Nessa espécie de corrida de revezamento, em que o bastão familiar é transmitido de uma geração à outra, Maike, discretamente, decide caminhar intuitivamente? - por outras sendas.

A cena final do romance de Saavedra,

\begin{abstract}
a avó abriu os olhos, recompôs o corpo, ajeitou o cabelo, a ponta do xale, como se aquela ausência não tivesse existido, depois apontou para o céu, veja, está começando a clarear, e realmente começava a amanhecer, ela se assustou, como era possível, há quantas horas estavam ali?, a peça já devia ter terminado. O primeiro impulso foi sair correndo, voltar ao teatro, ver se a filha ainda estava por lá, mas o cansaço tomara conta dela também, um dia inteiro caminhando, já não tinha energia para essas coisas, encostou a cabeça no ombro da avó, sentiase estranhamente calma, em seu rosto soprava uma brisa, um aroma de açucenas, e estava quase fechando os olhos quando sentiu que a avó a cutucava, ei, não vá dormir agora, justo agora, ela se endireitou, olhou em volta, a rua estava deserta, a avó procurava algo numa das sacolas, o que é, vó?, você vai ver, e, após muito procurar, tirou de lá um livro que ela nunca vira e disse, fiquei pensando, acho que é melhor esperar aqui mesmo, como tudo anda em círculos, mais cedo ou mais tarde, voltaremos ao ponto de partida. E agora preste atenção, a avó abriu o livro e começou a ler em voz alta. (SAAVEDRA, 2018, sem paginação) [grifos nossos]
\end{abstract}

com a ausência daquela que assume o papel de protagonista na ponta da linhagem familiar, Maike, ao mesmo tempo que retoma a metáfora da fita de Möbius, repetindo mais uma vez a caminhada circular dessas mulheres, nos deixa diante do dilema que acompanha as quase seiscentas páginas de narrativa de Desesterro e Com armas sonolentas juntas.

Em ambas as obras, a ideia de serialidade corpórea, em que os corpos femininos configuram-se como uma espécie de insumo destinado a alimentar o desejo/impulso masculino, é explorada. Naquele, de forma a estudar mais detidamente o quadro familiar construído num núcleo fechado composto pelas quatro gerações de Marias. Neste, o estudo ganha em amplitude e, numa metonímia, do particular para o todo, a narrativa passa a abarcar, pela forma como é construída a representante de cada geração, toda a temporalidade da ocupação territorial/corporal americana pós-colombiana, marcada esta que fora pela manutenção factual e simbólica de toda a sorte de violências - com especial "apresso" pela violação do corpo feminino.

Cabe mencionar, por fim, a sutil e quase imperceptível transformação por que passa a personagem dessa matriarca de ares míticos de Saavedra. A avó que fecha a narrativa do romance, apresentada anteriormente como iletrada, presa ao universo místico-anímico das florestas americanas, agora ressurge como alguém que não só possui uma cultura letrada observe-se o livro(/símbolo) que ela traz consigo dentro de suas sacolas, que antes traziam apenas ervas para a produção de garrafadas e emplastros -, mas como alguém que, agora, também domina perfeitamente um complexo instrumental citadino: pois é ela quem guia cuidadosamente o périplo das personagens pelos labirintos da cidade até à chegada ao teatro em que a bisneta encena o seu monólogo de vida.

É fortemente sintomático o fato de ser exatamente essa personagem da avó, que passa por toda a "saga civilizatória", a fechar a narrativa, sentada diante de um teatro, em pleno centro urbano, lendo um livro, numa cena em mise en abyme portanto, com uma fala que, a despeito de toda a sua "evolução existencial", ratifica a prisão a que as mulheres da família estão condenadas: "como tudo anda em círculos, voltaremos ao ponto de partida". 


\section{$=$ TRAMA $=$}

\section{CONSIDERAÇÕES FINAIS. CORPOS POSSÍVEIS}

Dessa breve leitura aproximativa dos romances Desesterro, de Sheyla Smanioto, e Com armas sonolentas, de Carola Saavedra, percebemos uma inabitual investida das autoras pelo complexo terreno da representação da família, sobretudo, a instauração de lugares de fala atribuídos com especial interesse àquelas personagens disruptivas.

Em contextos específicos, com propósitos distintos, Smanioto e Saavedra desenvolvem uma visada peculiar sobre formas de pertencimento e ação de mulheres dentro da linhagem familiar: Smanioto, numa via, partindo do duplo eixo da fome e da migração para elaborar os percursos das mulheres que compõem o seu elenco de Marias, de uma figura matriarcal mítica a servir de fonte e modelo de reproduções, de nomes e de valores, chegando à figura da trânsfuga que rompe o ciclo repetitivo de submissões e, no extremo de sua ação transgressora, é sacrificada para que a sua descendente dê continuidade à libertação do corpo feminino; Saavedra, noutra via, recupera o modelo romanesco clássico do bildungsroman, romance de formação, lugar majoritariamente marcado pela representação da formação de figuras masculinas, para construir uma saga protagonizada por cinco gerações de mulheres, um trabalho de arqueologia duma linhagem familiar que, num limite interpretativo, pode ser entendido como a própria formação dos arquétipos femininos no espaço familiar sul-americano, processo esse circunscrito num espaço/tempo que faz referência à cena - e não à metáfora da violação primordial do corpo feminino como o símile histórico do processo de invasão, ocupação e posterior colonização, cena esta instrumentalizada na narrativa como a materialidade do mito fundacional da miscigenação pacífica entre os povos na América do Sul.

Em Saavedra, a figura da personagem disruptiva é também trabalhada no sentido de instaurar a ruptura da imagem usada pela autora, a da fita de Möbius, para materializar o percurso circular dessas cinco gerações. Maike, à ponta da linhagem, apesar de distanciada em tudo dos mecanismos de opressão sofridos por suas ascendentes, e de ter crescido noutra realidade num contexto de aparente assepsia social, traz consigo, ainda assim, a marca da violência dupla, de gênero e de identidade, a cicatriz às costas resultante da facada recebida quando criança por um amigo supostamente esquizofrênico que, diante da morenidade pouco germânica da menina, teria tido seu primeiro surto psicótico.

Mesmo fechando a narrativa com a afirmação, feita pelas ancestrais, da circularidade, do eterno retorno dos infortúnios, o percurso em solitude de Maike, contudo, aponta para outra via, a de uma emancipação feminina possibilitada por meio do distanciamento. Nessa perspectiva, sua saída de cena, em determinado ponto da trama, assume um sentido de importante força simbólica. $\mathrm{O}$ abandono materno de que fora vítima ao ser deixada num bosque, ainda com dias de vida, acaba por ser-Ihe a chave para a sobrevivência, para um outro caminho de vida. Dessa forma, a ruptura, incialmente imposta, com a linhagem familiar, a despeito de toda a sua empresa na tentativa de recuperar os laços familiares biológicos e de reaproximação a uma ancestralidade brasileira apenas intuída, torna-se-lhe, por fim, a única via possivel.

Numa visada comparatista, observamos em ambas as obras a presença motriz, nos termos de Vuillemin ${ }^{14}$, de um tropismo negativo, isto é, de um imperativo do afastamento para a autopreservação, tanto para Scarlett quanto para Maike, com formas e condições específicas, adaptado ao contexto de cada uma, como meio possível de sobreviver ao circuito fechado de

\footnotetext{
${ }^{14}$ Em seu Essai sur la signification de la mort, o filósofo Jules Vuillemin toma por empréstimo a terminologia da biologia, especificamente a categoria tropisme [tropismo], para observar o comportamento de autodefesa/autopreservação presente em todo ser, em condições normais, diante da ameaça da morte. No caso específico, a fórmula empregada pelo autor é o do tropismo negativo, ou seja, o do afastamento quase que instintivo do ser em relação ao objeto de ameaça em prol da autopreservação. Cf. VUILLEMIN, J. Essai sur la signification de la mort. Paris: PUF, 1948, passim.
} 


\section{$=$ TRAMA $=$}

violências que pesa sobre a família e que, geração após geração, é retroalimentado pelos mesmos dispositivos sociais e históricos - em larga medida orientados por um macho-centrismo de profundas raízes ibéricas.

Das referências feitas inicialmente à Annie Ernaux e Fatou Diome, passando por Sheyla Smanioto e Carola Saavedra, percebemos, aqui também, nesse espaço virtual que aproxima semelhanças e especificidades a partir de lugares, a priori, completamente dessemelhantes a periferia paulistana de Smanioto, o interior fluminense de Saavedra, a costa senegalesa de Diome, o vilarejo normando de Ernaux -, a tessitura de uma linhagem de escritoras, cada uma à sua forma, travando batalhas em níveis específicos contra a violência exercida sobre o corpo feminino, a "vingar a sua raça", para recuperarmos o impulso inicial daquela jovem de dezesseis anos que ousava sonhar, um dia, ser escritora.

Longe de querermos apagar todo e qualquer traço de especificidade dessas autoras com o objetivo de identificarmos um bloco de características comuns e permanentes nessas vozes, temos em conta a conhecida advertência de Iris M. Young: "É um erro qualquer tentativa de isolar o gênero de identidades de raça, classe, idade, sexualidade, etnicidade etc. para desvendar os atributos, a experiência ou as opressões que as mulheres têm em comum" (YOUNG, 2003,114).

Dessa forma, tentamos desenvolver esse exercício de aproximação de escritas não por meio do apagamento das distinções, mas nos movendo dentro da ideia proposta pela teórica de entendermos o conceito de gênero como uma serialidade. A partir desse enfoque, portanto, proposto por Young, procuramos observar, aqui, os mecanismos de (re)produção da violência contra o corpo feminino. Nesse entendimento, a noção de grupo social, formado este na chave da serialidade constitutiva de seus membros, permite-nos compreender, dentro das suas especificidades, das suas particularidades, mas não isolados, as formas como esses corpos são atingidos por um tipo específico de violência que se fundamenta a partir de uma condição comum: o gênero.

\section{REFERÊNCIAS}

ADORNO, T. W. O que significa elaborar o passado. Trad. Wolfgang Leo Maar. Disponível em :

<bit.ly/2JL1z46>. Acessado em: 10 outubro 2019.

ARIES, P. História social da criança e da família. Rio de Janeiro: LTC, 1981.

BERND, Z. e SOARES, T. Modos de transmissão intergeracional em romances da literatura brasileira atual. Alea: Estudos Neolatinos. Rio de Janeiro: UFRJ, 2016.

BORGES, M. E. e OLIVEIRA, J. R. de. Retratos memoriais: nascimento/morte da linhagem familiar burguesa.

Fênix Revista de História e Estudos Culturais. Maio/jun/jul/ago, vol. 9, ano IX, n. ${ }^{\circ}$ 2, 2012.

BOURDIEU, P. A dominação masculina. Rio de Janeiro: Bertrand Brasil, 1999.

DA MATA, A. L. N. Como vai a família? As reconfigurações da instituição familiar no imaginário do romance brasileiro contemporâneo. Revue d'études ibériques et ibéro-américaines, vol. 2, 2012.

DALCASTAGNÈ, R. A personagem do romance brasileiro contemporâneo: 1990-2004. Estudos de Literatura Brasileira Contemporânea, n. ${ }^{\circ}$ 26, p. 13-71, 2005.

ERIBON, D. La société comme verdict - classes, identités, trajectoires. Paris: Flammarion, 2014.

GIRARD, R. Le bouc émissaire. Paris: Grasset, 1982.

JAQUET, C. Les Transclasses - ou la non-reproduction. Paris: PUF, 2014.

LUGONES, M. Rumo a um feminismo descolonial. Estudos Feministas. Florianópolis, dez. 2014.

SAAVEDRA, C. Com armas sonolentas. São Paulo: Cia das Letras, 2018.

SMANIOTO, S. Desesterro. Rio de Janeiro: Record, 2015.

VAINFAS, R. Trópico dos pecados. Rio de Janeiro: Civilização Brasileira, 1989.

YOUNG, I. M. O género como serialidade. Pensar as mulheres como um colectivo social. Revista Ex Aequo Associação Portuguesa de Estudos sobre Mulheres. Lisboa, n. 8. p. 113-139, 2003.

Recebido em 03-03-2020 Aceito em 24-05-2020 